\title{
Modeling and prediction of HAZ using finite element and neural network modeling
}

\author{
Edwin Raja Dhas, J. ${ }^{\mathrm{a},{ }^{*}}$, Somasundaram, K. ${ }^{\mathrm{b}}$ \\ aDepartment of Automobile Engineering, Noorul Islam Centre for Higher Education, Kumaracoil, India \\ ${ }^{b}$ Department of Production Engineering, National Institute of Technology, Tiruchirappalli, India
}

\begin{abstract}
A B S T R A C T
With the increasing demands for product variety and quality level the need to eliminate human operator from the feedback path for welding process correction is evident. Of the several manufacturing methods welding alone has defined true automation. Success of automation depends on effective and efficient decision making tools. Neural network is applied to intelligent weld control. In Submerged Arc Welding (SAW), selecting appropriate values for process variables is essential to control heat affected zone (HAZ) dimensions and get the required bead size and quality. Also, conditions must be selected that will ensure a predictable and reproducible weld bead. This paper proposes the modeling and prediction of dimensions of Heat-Affected Zone for SAW process using Finite Element Analysis (FEA) and Artificial Neural Network (ANN). The dimensions of HAZ for SAW are modeled are simulated using FEA using the process variables such as welding current, arc voltage, arc efficiency and welding speed and the results are used as the learning file for ANN model. The developed ANN model is forwarded to predict the dimensions of HAZ and the results are compared with simulated FEA results. The developed method is found to be time consuming, competent and cost effective.
\end{abstract}

\begin{tabular}{l} 
A R T I C L E I N F O \\
\hline Keywords: \\
Heat-affected zone (HAZ) \\
Finite element analysis \\
Artificial neural network \\
Submerged arc welding \\
${ }^{*}$ Corresponding author: \\
edwinrajadhas@rediffmail.com \\
(Edwin Raja Dhas, J.)
\end{tabular}

(C) 2013 PEI, University of Maribor. All rights reserved.

\section{References}

[1] Bradstreet, B. J. (1969). Effect of welding conditions on cooling rate and hardness in the heat affected zone, Welding Journal, Vol. 48, 499s-504s.

[2] Rajesh, Kumar., Rupinder, Singh. (2007). Effect of process variables on HAZ in submerged arc welds of structural pipes, Central Manufacturing Institute, Vol. 6, 23-30.

[3] Radhakrishnan, B.; Zacharia, T. (1993). On the prediction of HAZ grain size using Monte Carlo simulation, Presented at the American Welding Society International Conference on Modeling and Control of Joining Processes, Orlando, FL, 1993.

[4] Kuo, H-C., Wu, L.-J. (2000). Prediction of heat-affected zone using Grey theory, Journal of Materials Processing Technology, Vol. 120, 151-168.

[5] Schajer, G. S. (1981). Application of finite element calculations to residual stress measurements, ASME Journal of Engineering Materials and Technology, Vol. 103, 157-163.

[6] Nied, H. A. (1984). The finite element modeling of the resistance spot welding process, Welding Journal, Vol. 63, 123-132.

[7] Yurioka, N., Okumura, M., Kasuya, T., Cotton, H. J. (1987). Prediction of HAZ hardness of transformable steels, Metals Construction, Vol. 19, 217-223.

[8] Karlsson, R. I., Josefson, B. L. (1990). Three-dimensional finite element analysis of temperatures and stresses in a single-pass butt-welded pipe, ASME Journal of Pressure Vessel Technology, Vol. 112, 76-84.

[9] Keesentini, A., Chevalier, G., Louati, J., Riviere, A., Haddar, M. (2007). F.E.M. of the drilling machine - tool including the gyroscopic effect, International Journal of Advances in Production Engineering \& Management, Vol. 2, 63-78. 
[10] Brown, S., Song, H. (1992). Finite element simulation of welding of large structures, ASME Journal of Engineering for Industry, Vol. 114, 441-451.

[11] Grong, O., Myhr, O. R. (1993). Modeling of the strength distribution in the heat-affected zone of 6082-T6 aluminum weldments, Mathematical Modelling of Weld Phenomena, The Institute of Materials. London, 300-311.

[12] Gunaraj, V., Murugan, N. (2002). Prediction of heat-affected zone characteristics in submerged arc welding of structural steel pipes, Welding Research Supplement, 94-98.

[13] Ghosh, A., Chattopadhyaya, S. (2011). Prediction of HAZ width of submerged arc welded plates, Advanced Materials Research, Vol. 284-286, 2481-2484.

[14] Datta, S., Bandyopadhyay, A., Kumar Pal, P. (2008). Application of Taguchi philosophy for parametric optimization of bead geometry and HAZ width in submerged arc welding using a mixture of fresh flux and fused flux, International Journal of Advanced Manufacturing and Technology, Vol. 36, 7-8, 689-698. 